\title{
UNIVERSITY OF MIAMI RADIOCARBON DATES IX
}

\author{
D PIEPGRAS and J J STIPP
}

Department of Geology, University of Miami, Coral Gables,

Florida 33124

The following radiocarbon measurements are a partial list of geologic samples dated since September 1975. The technique used is described in $\mathrm{R}, \mathrm{v} 18$, p 210-220. Dates are calculated using a ${ }^{14} \mathrm{C}$ half-life of $5568 \mathrm{yr}$ and errors are reported as one standard deviation. This includes only the counting errors on the sample, background and modern standard.

\section{ACKNOWLEDGMENTS}

We are grateful to D Evans, Dept of Biology for the continued supplemental use of his Packard Tri-Carb 2003 liquid scintillation spectrometer.

\section{SAMPLE DESCRIPTIONS}

\section{Joulters Cays I series}

\section{A. Bahamas}

A piston core of oolites from Joulters Cays, Bahamas $\left(25^{\circ} 20^{\prime} \mathrm{N}\right.$, $\left.78^{\circ} 12^{\prime} \mathrm{W}\right)$. Samples coll to determine stratigraphy and date sedimentation rates. Coll 1975 and subm 1976 by P M Harris, RSMAS, Miami, Florida.

General Comment (DP): 1st of 3 projects from Joulters Cays area.

UM-801. 75-2-40A : 128 to $133 \mathrm{~cm}$

$625 \pm 155$

Outer layer.

UM-802. 75-2-40A : 128 to $133 \mathrm{~cm}$

Duplicate run of UM-801.

$760 \pm 75$

UM-803. 75-2-40A : 128 to $133 \mathrm{~cm}$

$1245 \pm 70$

Middle layer.

UM-804. 75-2-40A : 128 to $133 \mathrm{~cm}$

$2195 \pm 75$

Inner layer.

$2000 \pm 80$

UM-805. 75-2-40B : 217 to $222 \mathrm{~cm}$

Outer layer.

$2665 \pm 90$

UM-806. 75-2-40B : 217 to $222 \mathrm{~cm}$

Inner layer.

UM-807. 75-2-40C: 308 to $312 \mathrm{~cm}$

Outer layer.

$\mathbf{2 7 4 0} \pm \mathbf{8 5}$

UM-808. 75-2-40C: 308 to $312 \mathrm{~cm}$

Inner layer. 
UM-809. 75-2-40D : 397 to $402 \mathrm{~cm}$

Outer layer.

UM-810. 75-2-40D : 397 to $402 \mathrm{~cm}$

Inner layer.

UM-811. 75-2-40E: $430 \mathrm{~cm}$

$4560 \pm 105$

Whole oolite.

\section{Joulters Cays II series}

A piston core of oolites from Joulters Cays, Bahamas $\left(25^{\circ} 18^{\prime} \mathrm{N}\right.$, $\left.78^{\circ} 13^{\prime} \mathrm{W}\right)$. Samples coll to determine stratigraphy and date sedimentation rates. Coll 1976 by P M Harris, RSMAS, Miami, Florida; subm 1976 by $\mathrm{T}$ Dlugos, Univ Miami.

General Comment (DP): 2nd of 3 projects from Joulters Cays area; this correlates to Joulters Cays I series. Only outer $40-50 \%$ of oolites were dated.

UM-794. 76-2-67 : 0 to $2 \mathrm{~cm}$

$$
\begin{array}{r}
910 \pm 80 \\
1235 \pm 75 \\
1580 \pm 80 \\
2640 \pm 100 \\
4005 \pm 90 \\
4090 \pm 100 \\
4935 \pm 85
\end{array}
$$$$
\text { UM-795. 76-2-67 : } 70 \text { to } 72 \mathrm{~cm}
$$

UM-796. 76-2-67 : 140 to $143 \mathrm{~cm}$

UM-797. 76-2-67 : 210 to $212 \mathrm{~cm}$

UM-798. 76-2-67 : 350 to $352 \mathrm{~cm}$

UM-799. 76-2-67 : 420 to $422 \mathrm{~cm}$

UM-800. 76-2-67 : 468 to $470 \mathrm{~cm}$

Calcitic mud.

\section{Joulters Cays III series}

Hand-picked oolites from S end of Joulters Cay, Bahamas $\left(25^{\circ} 17^{\circ}\right.$ $\mathrm{N}, 78^{\circ} 07^{\prime} \mathrm{W}$ ). Samples coll along a transect at right angles to $\mathrm{NW}$-SE trending island. Where possible, loose ooids were coll under the hardened crust of island. Only the outer $10-15 \%$ of ooids in the $250 \mathrm{~m}$ to $420 \mathrm{~m}$ range were dated. Study for correlation of island age and formation with active shoal. Coll and subm 1976 by P M Harris and B D Clarke, RSMAS, Miami, Florida.

General Comment (DP): last of 3 projects from Joulters Cays area. Dates are reported in sequential order from $\mathrm{E}$ to $\mathrm{W}$.

UM-783. SAM 1 SHO

$$
\mathbf{3 0 0} \pm \mathbf{7 0}
$$

Subtidal shoal in $1 \mathrm{~m}$ water.

UM-784. SAM 2 BEA

$$
1915 \pm 75
$$

Marine beach, intertidal zone.

UM-785. SAM 2 BEA

Duplicate run of UM-784. 
UM-786. SAM 2 BEA

Triplicate run of UM-784.

$103.7 \pm 1.1 \%$ modern

UM-787. SAM 3 SWW

$<195$

Marine beach ridge crest, supratidal zone.

UM-788. SAM 4 STA 2

$580 \pm 75$

Marine beach ridge crest, supratidal zone.

UM-789. SAM 5 STA 2-C

$910 \pm 85$

Marine beach ridge crest, supratidal zone.

UM-790. SAM 6 STA 3

$390 \pm 120$

Marine beach trough, supratidal zone.

UM-791. SAM 7 STA 3-E

Marine beach ridge crest, supratidal zone.

$500 \pm 75$

UM-792. SAM 8 STA 4

$<230$

Marine beach ridge crest, supratidal zone.

UM-793. SAM 9 STA 6

Marine beach ridge crest, supratidal zone.

$430 \pm 75$

\section{Eleuthera Bank series}

Several samples of oolites and Strombus coll in lithified fragments from submerged shoals on Eleuthera Bank, Bahamas $\left(24^{\circ} 50^{\prime} \mathrm{N}, 76^{\circ} 25^{\prime}\right.$ $\mathrm{W})$. Crust samples found in situ on shoal and clast samples found unattached on shoal. Only outer $15 \%$ of oolites were dated. Dates to find correlation between crust and clast lithification. Coll 1975 by J Dravis, RSMAS, Miami, Florida; subm 1976 by J Donnellan, Univ Miami.

UM-769. SC-182

$102 \pm 1.4 \%$ modern

Sample consists of cementing material around oolites from crust of oolitic shoal. Coll in $1 \mathrm{~m}$ water, exposed at low tide.

UM-770. SC-202

$495 \pm 75$

Oolite crust from similar shoal as UM-769 coll in $0.5 \mathrm{~m}$ water, not exposed at low tide.

UM-771. E-29-3

$\mathbf{8 4 5} \pm 80$

Oolite crust coll from shoal flank in water $4 \mathrm{~m}$ deep.

UM-772. E-29-2

$1545 \pm 85$

Oolite clast found near shoal flank in water $5 \mathrm{~m}$ deep.

UM-773. E-29-1A

$550 \pm 215$

Strombus embedded in oolites coll as crust in water $4 \mathrm{~m}$ deep.

UM-776. E-29-1A

$895 \pm 65$

Duplicate run of UM-773. 


\section{UM-774. SC-89B}

Shell material embedded in oolitic clast from water $5 \mathrm{~m}$ deep.

UM-775. SC-36

Shell material from oolitic crust in water $30 \mathrm{~cm}$ deep, exposed at low tide.

\section{B. Mid-Atlantic}

\section{Mid-Atlantic Abyssal Plain series}

Two cores of pelagic ooze coll on opposite sides of the Mid-Atlantic ridge. Date sedimentation rates for regions adjacent to continents and for comparison to Mid-Atlantic Ridge sedimentation rates. Core P6903-56 $\left(16^{\circ} 36^{\prime} \mathrm{N}, 58^{\circ} 03.5^{\prime} \mathrm{W}\right)$ and Core P7008-25 $\left(08^{\circ} 01.7^{\prime} \mathrm{N}, 21^{\circ} 04.3^{\prime} \mathrm{W}\right)$ are both gravity cores from abyssal plain near base of Mid-Atlantic Ridge. Coll 1969 and 1970 by K Boström, RSMAS, Miami, Florida; subm 1976 by T Damon, Univ Miami.

General Comment (TD): samples presumably influenced by continental sediments and may be affected by slumping.

UM-812. P7008-25: 10 to $20 \mathrm{~cm}$

UM-813. P7008-25: 50 to $60 \mathrm{~cm}$$$
9400 \pm 80
$$

$\mathbf{3 0 , 8 6 0}+\mathbf{9 4 5}$

UM-822. P7008-25: 80 to $90 \mathrm{~cm}$

$32,945+1165$

UM-814. P7008-25: 90 to $100 \mathrm{~cm}$

$32,495+1385$

UM-823. P7008-25: 100 to $110 \mathrm{~cm}$

$>37,645$

UM-815. P7008-25: 130 to $140 \mathrm{~cm}$

$26,945 \pm 445$

UM-816. P7008-25: 160 to $170 \mathrm{~cm}$

$33,390+1210$

UM-817. P6903-56: 0 to $10 \mathrm{~cm}$

$7615 \pm 130$

UM-818. P6903-56: 35 to $45 \mathrm{~cm}$

$23,335 \pm 320$

UM-821. P6903-56: 53 to $63 \mathrm{~cm}$

$>34,945$

UM-819. P6903-56: 70 to $80 \mathrm{~cm}$

$25,100 \pm 460$

UM-820. P6903-56: 105 to $115 \mathrm{~cm}$

$25,280+625$

\section{Mid-Atlantic Ridge series}

Nine gravity cores of pelagic ooze from various locations on the MidAtlantic Ridge. Continuation of a study on sedimentation rates along ridge ( $\mathrm{R}, \mathrm{v}$ 18, p 407-412). Coll 1965 and 1970 by $\mathrm{K}$ Boström, RSMAS, Miami, Florida; subm 1975 and 1976 by D Grigoriev. 
General Comment (DG): elemental analyses indicate terrigenous influence on sediments from ridge flanks.

Core P6511-29. Eastern flank, Mid-Atlantic Ridge $\left(27^{\circ} 42^{\prime} 5^{\prime \prime} \mathrm{N}, 37^{\circ} 13^{\prime}\right.$ $\left.0^{\prime \prime} \mathrm{W}\right)$.
UM-888. P6511-29: 0 to $15 \mathrm{~cm}$
$11,145 \pm 115$
UM-889. P6511-29: 25 to $40 \mathrm{~cm}$
$27,820+580$
UM-890. P6511-29: 25 to $40 \mathrm{~cm}$
$29,700+635$
Duplicate run of UM-889.
$23,245+655$
UM-892. P6511-29: 50 to $65 \mathrm{~cm}$
$33,460+1735$
UM-893. P6511-29: 80 to $95 \mathrm{~cm}$

Core P6511-31. Eastern flank Mid-Atlantic Ridge (26 $\left.16^{\circ} \mathrm{N}, 43^{\circ} 30^{\prime} \mathrm{W}\right)$.

$\begin{array}{llr}\text { UM-894. } & \text { P6511-31: } 5 \text { to } 15 \mathrm{~cm} & 13,100+740 \\ \text { UM-895. } & \text { P6511-31: } 30 \text { to } 40 \mathrm{~cm} & 21,530 \pm 275 \\ \text { UM-896. } & \text { P6511-31: } 60 \text { to } 70 \mathrm{~cm} & 30,720+740 \\ \text { UM-897. } & \text { P6511-31 : } 90 \text { to } 100 \mathrm{~cm} & >37,330\end{array}$

Core P7008-17. Western flank Mid-Atlantic Ridge $\left(0^{\circ} 48.8^{\prime} \mathrm{N}, 31^{\circ} 27^{\prime} \mathrm{W}\right)$.

UM-714. P7008-17: 0 to $15 \mathrm{~cm}$

$\mathbf{4 1 4 5} \pm \mathbf{8 5}$

UM-900. P7008-17 : 23 to $35 \mathrm{~cm}$

$13,500 \pm 145$

UM-715. P7008-17 : 40 to $55 \mathrm{~cm}$

$16,720 \pm 265$

UM-716. P7008-17 : 80 to $95 \mathrm{~cm}$

$29,990+1600$

UM-717. P7008-17 : 115 to $130 \mathrm{~cm}$

$31,130+625$

Core P7008-18. Western flank Mid-Atlantic Ridge $\left(1^{\circ} 27.2^{\prime} \mathrm{N}, 30^{\circ} 40.1^{\prime}\right.$ W).

UM-898. P7008-18: 20 to $35 \mathrm{~cm}$

$13,210 \pm 165$

Core P7008-21. Eastern flank Mid-Atlantic Ridge $\left(4^{\circ} 27.3^{\prime}\right.$ N, $25^{\circ} 09.3^{\prime}$ $\mathrm{W})$.

UM-899. P7008-21 : 25 to $35 \mathrm{~cm}$

$18,750 \pm 195$ 
Core P7008-41. Eastern flank Mid-Atlantic Ridge $\left(12^{\circ} 52.9^{\prime} \mathrm{N}, 38^{\circ} 01.5^{\prime}\right.$ W).

UM-718. P7008-41 : 0 to $15 \mathrm{~cm}$

$$
\begin{array}{r}
9190 \pm 150 \\
27,350 \pm 550 \\
22,430+1220 \\
+15,170 \pm 540 \\
23,195 \pm 420
\end{array}
$$

UM-901. P7008-41 : 25 to $35 \mathrm{~cm}$

UM-719. P7008-41: 40 to $55 \mathrm{~cm}$

UM-720. P7008-41 : 80 to $95 \mathrm{~cm}$

UM-721. P7008-41 : 120 to $135 \mathrm{~cm}$

Core P7008-44. Western flank Mid-Atlantic Ridge $\left(12^{\circ} 56.9^{\prime} \mathrm{N}, 42^{\circ} 27.6^{\prime}\right.$ W).

UM-738. P7008-44: 0 to $20 \mathrm{~cm}$

UM-886. P7008-44: 0 to $20 \mathrm{~cm}$

Duplicate run of UM-738.

UM-739. P7008-44: 45 to $60 \mathrm{~cm}$

UM-740. P7008-44: 95 to $110 \mathrm{~cm}$

UM-741. P7008-44: 145 to $160 \mathrm{~cm}$
$22,600 \pm 255$

$32,975+680$

$15,410 \pm 160$

$27,980 \pm 450$

$30,065 \pm 455$

REFERENCES

Eldridge, K L, Stipp, J J, Hattner, J, and McDougal, E, 1975, University of Miami radiocarbon dates IV: Radiocarbon, v 17, p 407-412.

Stipp, J J, Eldridge, K L, and Cadwell, R, 1976, University of Miami radiocarbon dates VI: Radiocarbon, v 18, p 210-220. 